\title{
MIR20B wt Allele
}

National Cancer Institute

\section{Source}

National Cancer Institute. MIR20B wt Allele. NCI Thesaurus. Code C81898.

Human MIR20B wild-type allele is located in the vicinity of Xq26.2 and is 68 bases in length. This allele, which encodes MIR20B pre-miRNA, plays a role in the regulation of gene expression. Alteration in the expression of this gene is associated with medulloblastoma. 